At-Tijaroh : Jurnal Ilmu Manajemen dan Bisnis Islam
Volume 5 Nomor 2 Ed. Juli-Desember $2019:$ Hal 261-279
p-ISSN : 2356-492x
e-ISSN : 2549-9270

\title{
KONTRIBUSI INDUSTRI KEUANGAN NON-BANK (IKNB) KONVENSIONAL DAN SYARIAH TERHADAP PEREKONOMIAN INDONESIA
}

\author{
Nabila Ilmalina Faza ${ }^{1}$, Muhammad Ghafur Wibowo ${ }^{2}$ \\ 1,2 Universitas Islam Negeri Sunan Kalijaga Yogyakarta \\ 1,2 Jl. Laksda Adisucipto, Papringan, Catur Tunggal, Sleman, D.I. Yogyakarta \\ 1 nabilafaza13@gmail.com \\ 2 gus_fur2001@yahoo.com
}

\begin{abstract}
This research aims to empirically examine the contributions of Conventional NonBank Financial Intermediaries (Conventional NBFIs) and Islamic Non-Bank Financial Intermediaries (Islamic NBFIs) development on economic growth in Indonesia. This study used Vector Autoregression (VAR) and Vector Error Correction Model (VECM) to test the causality and long-run relationship between the two intermediaries by using time series data over the period spanning 2014 to 2017. The results show an evidence of bidirectional causality view and a long-run relationship between the development of Conventional Non-Bank Financial Intermediaries (Conventional NBFIs) and Islamic Non-Bank Financial Intermediaries (Islamic NBFIs) on economic growth in Indonesia. The result also proves that Islamic NonBank Financial Intermediaries (Islamic NBFIs) is more resistant to economic growth shock than Conventional Non-Bank Financial Intermediaries (Conventional NBFIs).
\end{abstract}

Keywords: Conventional NBFIs, Islamic NBFIs, Economic Growth

\begin{abstract}
Abstrak
Penelitian ini bertujuan untuk mengetahui kontribusi perkembangan Industri Keuangan Non-Bank (IKNB) Konvensional dan Industri Keuangan Non-Bank (IKNB) Syariah pada pertumbuhan ekonomi Indonesia. Penelitian ini menggunakan Vector Autoregression (VAR) pada Industri Keuangan Non-Bank (IKNB) Konvensional dan Vector Error Correction Model (VECM) pada Industri Keuangan Non-Bank (IKNB) Syariah untuk menguji hubungan kausalitas dan jangka panjang antara keduanya terhadap pertumbuhan ekonomi. Data yang digunakan dalam penelitian ini merupakan data time series bulanan dari periode 2014 hingga 2017. Hasil penelitian ini menunjukkan bahwa terdapat hubungan kausalitas dua arah (bidirectional causality view) dan hubungan jangka panjang antara perkembangan IKNB baik Konvensional maupun Syariah terhadap pertumbuhan ekonomi. Hasil penelitian ini juga membuktikan bahwa IKNB Syariah lebih tahan terhadap shock dari pertumbuhan ekonomi dibandingkan IKNB Konvensional.
\end{abstract}

Kata Kunci: IKNB Konvensional, IKNB Syariah, Pertumbuhan ekonomi 


\section{PENDAHULUAN}

Sektor keuangan yang terdiversifikasi dengan baik merupakan kunci untuk mendukung tujuan pembangunan ekonomi, penciptaan lapangan kerja yang lebih luas, dan perbaikan taraf hidup bagi seluruh rakyat Indonesia (World Bank, 2006). Dampak positif dari perkembangan sektor keuangan pada pertumbuhan ekonomi didasarkan pada fungsi sektor keuangan itu sendiri, yaitu mobilisasi dan alokasi sumber daya yang dibutuhkan untuk melakukan kegiatan investasi produktif oleh berbagai pelaku ekonomi (Islam dan Shah, 2012). Mishkin (2010) berpendapat bahwa peningkatan ketersediaan instrumen dan lembaga keuangan akan mengurangi biaya transaksi serta informasi, menyediakan jasa likuiditas, mengembangkan pembagian risiko, menyelesaikan masalah-masalah informasi yang pada gilirannya akan mempengaruhi tingkat tabungan, keputusan investasi, serta inovasi teknologi.

Sektor keuangan Indonesia sangat didominasi oleh industri perbankan. Sektor perbankan menguasai hampir 74 persen aset keuangan Indonesia pada tahun 2014 (OJK, 2016). Setelah mengalami restrukturisasi pasca krisis, sektor perbankan Indonesia menjadi lebih kuat, memiliki rasio kecukupan modal dan profitabilitas yang lebih tinggi. Sebagian besar dari bank (yang dahulu swasta) yang diambil alih oleh pemerintah telah ditutup atau dijual kembali kepada sektor swasta. Pemerintah juga telah mulai melepas saham minoritasnya di bank-bank milik negara. Peraturan dan pengawasan sektor telah diperkuat secara substansial, jaminan merata atas simpanan yang ada di bank sejak krisis, berangsur-angsur dihilangkan seiring diterapkannya program jaminan simpanan. Namun meski ada perbaikan-perbaikan ini agenda reformasi lebih lanjut yang signifikan masih tetap berkaitan dengan sektor perbankan (World Bank, 2006).

Terlepas dari besarnya perbaikan akhir-akhir ini, sektor perbankan bukanlah merupakan sumber modal jangka panjang. Bank-bank di Indonesia memperoleh sebagian besar pendanaannnya dari deposito jangka pendek, dan lebih dari 90\% simpanan bank memiliki masa jatuh tempo kurang dari 1 bulan. Pengelolaan aktiva pasiva yang bijak mengharuskan bank menawarkan pinjaman jangka pendek dengan floating rate. Oleh karena itu struktur kewajiban ini sangat membatasi kemampuan bank untuk membiayai aset jangka panjang (World Bank, 2006).

Munculnya Industri Keuangan Non-Bank (IKNB) diharapkan mampu menjadi problem solver untuk permasalahan perekonomian Indonesia tersebut, serta mampu menjadi salah satu instrumen perekonomian jangka panjang. Industri Keuangan Non-Bank (IKNB) yang dikembangkan dengan baik berpotensi memenuhi sasaran pembangunan ekonomi. Dengan menyediakan jasa keuangan tambahan dan alternatif, Industri Keuangan Non-Bank (IKNB) memperbaiki akses keuangan umum di seluruh sistem. Industri Keuangan Non-Bank (IKNB) juga membantu mempermudah investasi dan pembiayaan jangka panjang, yang seringkali menjadi tantangan dalam tahap-tahap awal pembangunan sektor keuangan 
berorientasi bank. Pertumbuhan lembaga simpanan kontraktual seperti perusahaan asuransi, dan dana pensiun memperluas kisaran produk yang tersedia bagi masyarakat dan perusahaan yang memiliki sumber daya untuk diinvestasikan. Lembaga ini juga menjadi saingan bagi simpanan bank, sehingga memobilisasi dana jangka panjang yang diperlukan untuk pengembangan sektor pasar modal serta pasar obligasi korporasi, keuangan infrastruktur, pasar obligasi hipotik, sewa guna usaha, anjak piutang, dan modal ventura. Lembaga simpanan kolektif juga memungkinkan pengelolaan dana yang lebih baik sambil membantu mengurangi potensi risiko sistem melalui penghimpunan sumber daya, alokasi risiko, dan penerapan tehnik-tehnik pengelolaan portofolio yang meneruskan risiko ke seluruh bagian sistem keuangan yang terdiversfikasi (World Bank, 2012).

Potensi-potensi Industri Keuangan Non-Bank (IKNB) tersebut tentunya juga dimiliki baik oleh Industri Keuangan Non-Bank (IKNB) Konvensional maupun Syariah. Industri Keuangan Non-Bank (IKNB) Syariah berprinsip berdasarkan syariah atau dalam transaksinya tidak mengandung setidaknya tiga hal yaitu riba, gharar (ketidakjelasan), maysir (judi) yang diyakini sebagai penyebab dari ketidakstabilan serta krisis ekonomi yang terjadi di berbagai belahan dunia (Mardani, 2015:1-7). Industri Keuangan Non-Bank (IKNB) Syariah juga menggunakan paradigma risk sharing. Konsep ini akan membuat para pihak yang terlibat berhati-hati dalam menyalurkan pembiayaan atau dalam melakukan investasi (Chapra, 2008).

Pada periode tahun 2012 sampai dengan 2016 Industri Keuangan Non-Bank baik Konvensional maupun Syariah tumbuh cukup signifikan. Selama periode tersebut, IKNB Konvensional telah mengalami rata-rata pertumbuhan aset sebesar $14,4 \%$ per tahun, sedangkan IKNB Syariah mengalami rata-rata pertumbuhan aset sebesar 47,2\% per tahun. Pertumbuhan jumlah aset IKNB Konvensional dan Syariah dapat dilihat dalam grafik di bawah ini:

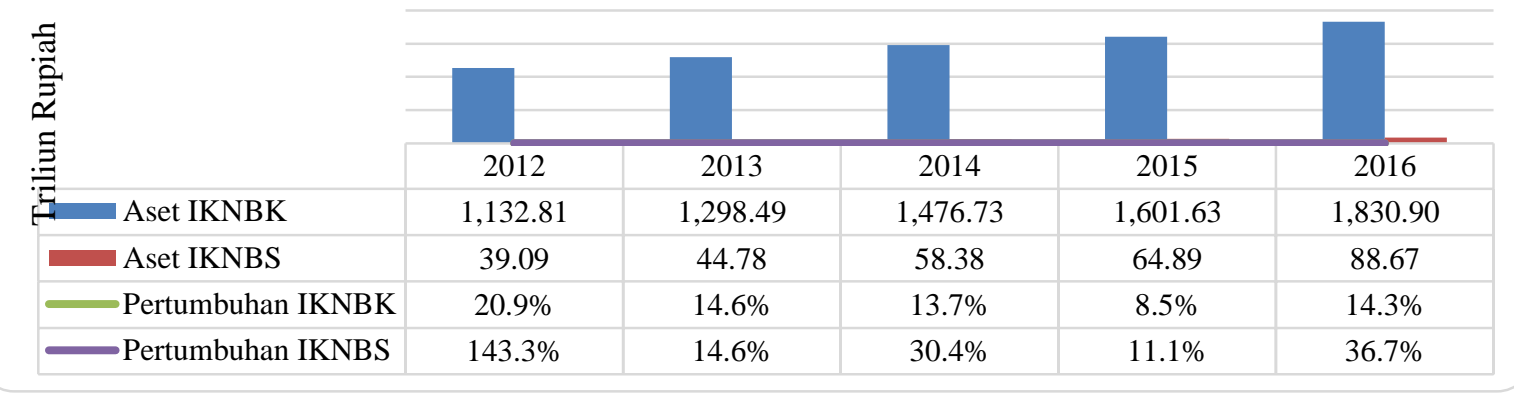

Sumber: Laporan OJK tentang Keuangan IKNB Konvensional \& Syariah (data diolah)

\section{Gambar 1 Pertumbuhan Jumlah Aset IKNB Konvensional dan Syariah}

Berdasarkan gambar di atas dapat diketahui bahwa aset IKNB Syariah hanya sebesar Rp 39,09 Triliun pada tahun 2012, jumlah ini jauh lebih kecil jika dibandingkan dengan aset IKNB Konvensional sebesar 1.132,81 Triliun pada tahun yang sama. Meskipun demikian, IKNB Syariah memiliki pertumbuhan aset yang jauh lebih pesat dibandingkan dengan IKNB Konvensional dengan rata-rata pertumbuhan 47, 2\% per tahun. Dari grafik tersebut juga dapat 


\section{4|Kontribusi Industri Keuangan Non-Bank (IKNB) Konvensional dan Syariah Terhadap Perekonomian Indonesia}

dilihat bahwa pola pertumbuhan aset IKNB baik Konvensional maupun Syariah cenderung serupa. Pertumbuhan tertinggi terjadi pada tahun 2012 sebesar 20,9\% untuk IKNB Konvensional dan 143,3\% untuk IKNB Syariah. Perlambatan pertumbuhan pada keduanya juga terjadi pada periode yang sama yaitu tahun 2015 .

Perkembangan IKNB Konvensional dan Syariah yang tinggi tersebut diharapkan dapat berkontribusi penuh terhadap pertumbuhan ekonomi Indonesia. Sejumlah besar penelitian telah menguji hubungan antara sektor keuangan dan pertumbuhan ekonomi menggunakan tehnik metodologis yang berbeda dengan berbagai indikator berkembangan sektor keuangan pada berbagai negara dan jangka waktu berbeda. Harrod (1939) dan Domar (1946) sebagaimana dikutip dalam Rama (2013) menyatakan bahwa pertumbuhan ekonomi dapat ditingkatkan melalui peningkatan investasi baru, sehingga rasio tabungan nasional dan pendapatan nasional menetukan tingkat pertumbuhan ekonomi.

Berdasarkan penelitian yang mengkaji hubungan antara sektor keuangan dan pertumbuhan ekonomi, setidaknya terdapat empat kemungkinan pendekatan yang dapat menjelaskannya, yaitu 1) Keuangan merupakan faktor penentu petumbuhan ekonomi (finance led-growth hypothesis) atau biasa disebut "supply leading view" (King dan Levine, 1993; Arestis et al., 1996; Horrison et al. 1999; Blackburn dan Hung, 1998; Fase dan Abma, 2003), 2) Keuangan mengikuti pertumbuhan ekonomi (growth-led finance hypothesis) atau biasa disebut "demand following view" (Habibullah, 2006), 3) Hubungan saling mempengaruhi antara sektor keuangan dan pertumbuhan ekonomi atau biasa disebut "the bidirectional causality view" (Schumpeter, 1912; Levine 1997; Odedokun, 1992, Luintel dan Khan, 1999; Unalmis, 2002), 4) Sektor keuangan tidak saling berhubungan atau disebut "the independent hypothesis" (Guryay, 2007, Al-Zuby, 2006).

Sebagian besar penelitian yang telah dilakukan berfokus pada perkembangan sektor perbankan dan pasar modal. Kedua sektor ini digunakan sebagai proxy perkembangan sektor keuangan pada telaah hubungan keuangan dan pertumbuhan ekonomi. Munculnya IKNB sebagai salah satu sub-sektor dalam perkembangan sektor keuangan masih dipandang sebelah mata. Secara empiris penelitian tentang hubungan antara perkembangan IKNB dan pertumbuhan ekonomi belum banyak dilakukan.

Melihat urgensi dari keberadaan IKNB Konvensional dan IKNB Syariah, serta perkembangan yang cukup pesat dari kedua sektor tersebut, maka penyusun memandang perlunya dilakukan penelitian terkait IKNB Konvensional dan IKNB Syariah di Indonesia. Penelitian ini berfokus untuk mengetahui ada atau tidaknya hubungan kausalitas antara perkembangan pada sektor IKNB Konvensional dan IKNB Syariah terhadap pertumbuhan ekonomi serta untuk mengetahui ada tidaknya hubungan jangka panjang antara keduanya. Setelah diketahui ada/tidaknya hubungan kausalitas dan jangka panjang, maka akan 
dilakukan komparasi terhadap kedua sektor tersebut untuk mengetahui sektor mana yang lebih berkontribusi terhadap perekonomian Indonesia.

\section{METODE PENELITIAN}

Berdasarkan sifat data, penelitian ini merupakan jenis penelitian kuantatif. Dalam penelitian ini, penyusun ingin menjelaskan hubungan kausal dan jangka panjang antara perkembangan Industri Keuangan Non-Bank (IKNB) Konvensional dan Industri Keuangan Non-Bank (IKNB) Syariah terhadap pertumbuhan ekonomi Indonesia.

Data yang digunakan dalam penelitian ini adalah data sekunder berupa data time series bulanan. Variabel perkembangan IKNB diproksikan dengan rasio jumlah asset IKNB baik konvensional maupun syariah terhadap PDB nominal, sedangkan variabel pertumbuhan ekonomi direpresentasikan oleh Indeks Produksi Industri (IPI). Untuk variabel pada penelitian Industri Keuangan Non-Bank (IKNB) Konvensional digunakan periode dari tahun 2014 bulan Juli hingga tahun 2017 bulan Februari, sedangkan untuk variabel pada penelitian Industri Keuangan Non-Bank (IKNB) Syariah digunakan periode dari tahun 2014 bulan Januari hingga tahun 2017 bulan Februari.

Metode yang digunakan dalam penelitian ini adalah model analisis Vector Autoregresion (VAR) dengan model regresi yang diformulasikan sebagai berikut:

$$
\begin{aligned}
& I P I_{t}=a_{1}+a_{2} I K N B K_{t}+a_{3} I P I_{t-1}+e_{1 t} \\
& I P I_{t}=a_{1}+a_{2} I K N B S_{t}+a_{3} I P I_{t-1}+e_{1 t}
\end{aligned}
$$

Dimana:

IPI

$$
\text { : Indeks Produksi Industri }
$$

IKNBK $\quad$ : Industri Keuangan Non-Bank (IKNB) Konvensional

IKNBS : : Industri Keuangan Non-bank (IKNB) Syariah

Di sisi lain, pergerakan pertumbuhan ekonomi (IPI) pada gilirannya akan mempengaruhi pergerakan IKNB Konvensional dan Syariah di masa yang akan datang sehingga dapat diformulasikan model regresi dengan persamaan sebagai berikut:

$$
\begin{aligned}
& I K N B K_{t}=\beta_{1}+\beta_{2} I P I_{t}+\beta_{3} I K N B K_{t-1}+e_{1 \text { 匟 }} \\
& I K N B S_{t}=\beta_{1}+\beta_{2} I P I_{t}+\beta_{3} I K N B S_{t-1}+e_{1 t}
\end{aligned}
$$

Dari persamaan 1 dan 2 terlihat adanya hubungan yang dinamis antara IPI dengan IKNB Konvensional dan Syariah. Kedua persamaan tersebut kemudian dapat disederhanakan dengan menyubtitusi persamaan 2 ke persamaan 1 yaitu:

$$
\begin{aligned}
& I P I_{t}=a_{11}+a_{12} I P I_{t-1}+a_{13} I K N B K_{t-1}+v_{1 t} \\
& I P I_{t}=a_{11}+a_{12} I P I_{t-1}+a_{13} I K N B S_{t-1}+v_{1 t}
\end{aligned}
$$

Dengan melakukan substitusi persamaan 1 ke 2 juga akan diperoleh persamaan sebagai berikut: 


$$
\begin{aligned}
& I K N B K_{t}=a_{21}+a_{22} I P I_{t-1}+a_{23} I K N B K_{t-1}+v_{2 t} \\
& I K N B S_{t}=a_{21}+a_{22} I P I_{t-1}+a_{23} I K N B S_{t-1}+v_{2 t}
\end{aligned}
$$

Persamaan 3 dan 4 dalam notasi matriks dapat dituliskan sebagai berikut:

$$
\begin{gathered}
Y_{t}=\left[\begin{array}{c}
I P I_{t} \\
I K N B K_{t}
\end{array}\right] ; A_{0}=\left[\begin{array}{l}
a_{11} \\
a_{12}
\end{array}\right] ; A=\left[\begin{array}{ll}
a_{12} & a_{13} \\
a_{22} & a_{23}
\end{array}\right] ; v_{t}=\left[\begin{array}{l}
v_{1 t} \\
v_{2 t}
\end{array}\right] \\
Y_{t}=\left[\begin{array}{c}
I P I_{t} \\
I K N B S_{t}
\end{array}\right] ; A_{0}=\left[\begin{array}{l}
a_{11} \\
a_{12}
\end{array}\right] ; A=\left[\begin{array}{ll}
a_{12} & a_{13} \\
a_{22} & a_{23}
\end{array}\right] ; v_{t}=\left[\begin{array}{l}
v_{1 t} \\
v_{2 t}
\end{array}\right]
\end{gathered}
$$

Sehingga persamaan $5 \mathrm{a}$ dan $5 \mathrm{~b}$ masing-masing bisa ditulis sebagai berikut:

$$
Y_{t}=A_{0}+A Y_{t-1}+v_{t}
$$

Secara garis besar langkah dalam analisis menggunakan model VAR terdiri dari uji stationeritas data, uji lag optimal, uji stabilitas VAR, uji kointegrasi, estimasi model VAR dengan Uji Kausalitas Granger, Impulse Respond Functiondan (IRF) dan Variance Decompotition (VD). Langkah-langkah tersebut dapat dijelaskan dalam gambar berikut ini:

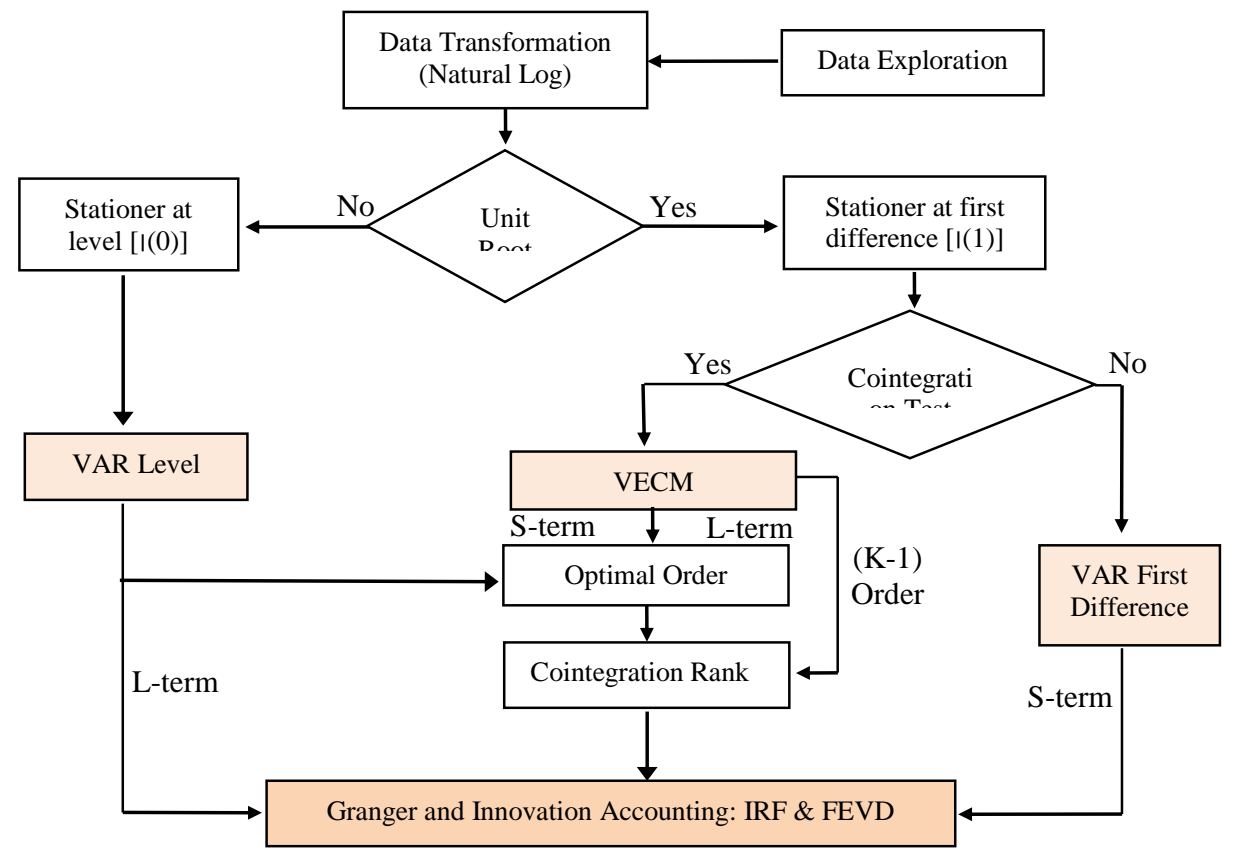

Sumber: Ascarya, 2009: 65

\section{Gambar 2 Tahap Analisis Vector Autoregression (VAR)}

Berikut penjelasan langkahnya secara mendetail:

Langkah 1: Menguji stationeritas data. Pada tahap ini semua data ditransformasikan ke dalam bentuk logaritma, kecuali data dalam bentuk presentase. Setelah itu dilakukan pengujian stationeritas data dengan menggunakan model Augmented Dickey-Fuller (ADF) dan Philips-Peron (PP). 
Langkah 2: Jika data stationer pada tingkat level maka dilanjutkan dengan VAR biasa (unrestricted $V A R$ ) Sedangkan jika data tidak stationer pada tingkat level, maka dimungkinkan adanya kointegrasi untuk melihat adanya hubungan jangka panjang. Namun sebelumnya harus tilakukan uji lag optimal. Jika terdapat kointegrasi maka model yang digunakan adalah model Vector Error Correction Model (VECM). Namun apabila tidak ada kointegrasi maka disebut VAR dengan data diferensi (VAR in difference)

Langkah 3:Uji stabilitas VAR dan lag optimal. Indikator uji lag optimal adalah Akaike Information Criterion (AIC), Schwarz Information Criterion (SC), dan Hannan Quinnon (HQ). Setelah diketahui lag optimal, dilakukan uji stabilitas VAR dari lag 1 sampai dengan lag optimal. Model VAR yang stabil akan menghasilkan estimasi yang tidak bias dari waktu ke waktu.

Langkah 4: Permodelan VAR (VAR Modeling). Setelah syarat dan ketentuan terpenuhi maka langkah selanjutnya adalah melakukan analisis VAR dengan lag optimalnya.

Langkah 5: Uji Kausalitas Granger. Uji kausalitas Granger bertujuan untuk melihat hubungan antar variabel, baik hubungan searah maupun hubungan saling mempengaruhi (timbal balik).

Langkah 6:Analisis Impulse Response Function (IRF) digunakan untuk melihat respon masing-masing variabel terhadap guncangan yang terjadi pada dirinya maupun pada variabel lain yang digunakan dalam model. Sedangkan Forecast Error Variance Decompotition (FEVD) digunakan untuk melihat kontribusi positif dari masing-masing variabel yang digunakan dalam model.

Dari keenam langkah di atas akan diperoleh hasil dari tujuan penelitian ini yaitu ada atau tidaknya hubungan kausalitas Granger dan hubungan jangka panjang yang terjadi pada kedua variabel yang diteliti.

\section{HASIL DAN PEMBAHASAN}

\section{Uji Stationeritas Data IKNB Konvensional}

Berikut hasil pengujian IKNB Konvensional dan IPI dengan metode ADF dan PP pada tingkat level: 
Tabel 1

Hasil Uji Stationeritas Metode ADF dan PP

IKNB Konvensional Tingkat Level

\begin{tabular}{lllccc}
\hline \multirow{2}{*}{ Test } & & \multicolumn{2}{c}{ IKNB Konvensional } & \multicolumn{2}{c}{ IPI } \\
\cline { 3 - 6 } & & T-statistik & Prob & T-statistik & Prob \\
\hline ADF test statistic & & $-4.090542^{* *}$ & 0.0184 & $-4.479070^{* * * *}$ & 0.0063 \\
Test critical value & 1\% level & -4.374307 & & -4.284580 & \\
& 5\% level & -3.603202 & & -3.562882 & \\
& 10\% level & -3.238054 & & -3.215267 & \\
PP test statistic & & -2.399957 & 0.3724 & $-4.427639^{* * *}$ & 0.0071 \\
Test critical value & 1\% level & -4.284580 & & -4.284580 & \\
& 5\% level & -3.562882 & & -3.562882 & \\
& 10\% level & -3.215267 & & -3.215267 & \\
\hline
\end{tabular}

Ket: ${ }^{* * *}$ dan ${ }^{* *}$ menunjukkan data stationer pada nilai kritis Mac Kinon 1\%, 5\%

Hasil uji stationeritas pada tabel 1 menunjukan bahwa variabel IKNB Konvensional stationer pada tingkat level berdasarkan metode ADF, tetapi belum stationer menurut metode PP. Adapun variabel IPI juga stationer di tingkat level berdasarkan metode ADF dan PP dengan t-statistik sebesar -4.479070 dan -4.427639 .

\section{Uji Stationeritas Data IKNB Syariah}

Berikut hasil pengujian IKNB Syariah dan IPI dengan metode ADF dan PP pada tingkat level:

\section{Tabel 2}

Hasil Uji Stationeritas Metode ADF dan PP IKNB Syariah Tingkat Level

\begin{tabular}{llcccc}
\hline \multirow{2}{*}{ Test } & & \multicolumn{2}{c}{ IKNB Syariah } & \multicolumn{2}{c}{ IPI } \\
\cline { 3 - 6 } & & T-statistik & Prob & T-statistik & Prob \\
\hline ADF test statistic & & -3.324705 & 0.0789 & $-4.400738^{* * *}$ & 0.0065 \\
Test critical value & 1\% level & -4.243644 & & -4.226815 & \\
& 5\% level & -3.544284 & & -3.536601 & \\
PP test statistic & 10\% level & -3.204699 & & -3.200320 & \\
Test critical value & 1\% level & -1.970062 & 0.5979 & $-4.167577^{* *}$ & 0.0116 \\
& 5\% level & -4.226815 & & -4.226815 & \\
& 10\% level & -3.536601 & & -3.536601 & \\
\hline
\end{tabular}

Ket: ${ }^{* * *},{ }^{* *}$ menunjukkan data stationer pada nilai kritis Mac

Kinon $1 \%, 5 \%$

Hasil uji stationeritas pada tabel 2 menunjukan bahwa variabel IPI stationer di tingkat level berdasarkan metode ADF dan PP. Untuk melakukan estimasi VAR/VECM diperlukan data yang stationer pada tingkatan yang sama. Berdasarkan hasil uji ADF dan PP pada tingkat level dapat disimpulkan bahwa perlu dilakukan uji stationeritas data pada tingkat diferensi pertama untuk menyamakan tingkat stationeritas data. Berikut hasil pengujian dengan metode ADF dan PP pada tingkat diferensi pertama. 
Tabel 3

Hasil Uji Stationeritas Metode ADF dan PP

IKNB Syariah Tingkat Diferensi Pertama

\begin{tabular}{|c|c|c|c|c|c|}
\hline \multirow{2}{*}{ Test } & & \multicolumn{2}{|c|}{ IKNB Syariah } & \multicolumn{2}{|c|}{ IPI } \\
\hline & & T-statistik & Prob & T-statistik & Prob \\
\hline ADF test statistic & & $-3.549976^{* *}$ & 0.0498 & $-7.272579^{* * *}$ & 0.0000 \\
\hline \multirow[t]{3}{*}{ Test critical value } & $1 \%$ level & -4.252879 & & -4.234972 & \\
\hline & $5 \%$ level & -3.548490 & & -3.540328 & \\
\hline & $10 \%$ level & -3.207094 & & -3.202445 & \\
\hline PP test statistic & & $-4.737314^{* * *}$ & 0.0028 & $-7.272579 * * *$ & 0.0000 \\
\hline \multirow[t]{3}{*}{ Test critical value } & 1\% level & -4.234972 & & -4.234972 & \\
\hline & $5 \%$ level & -3.540328 & & -3.540328 & \\
\hline & $10 \%$ level & -3.202445 & & -3.202445 & \\
\hline
\end{tabular}

Tabel 3 menunjukkan bahwa variabel IPI dan IKNB Syariah stationer pada tingat diferensi pertama dengan kedua metode.

\section{Uji Panjang Kelambanan (lag) Optimal IKNB Konvensional}

Berikut hasil pengujian lag optimal pada IKNB Konvensional:

\section{Tabel 4}

Hasil Pengujian Lag Optimal IKNB Konvensional (AIC dan SC)

\begin{tabular}{ccc}
\hline Lag & AIC & SC \\
\hline 1 & 0.996406 & 1.273952 \\
2 & 0.894640 & 1.361706 \\
3 & $0.564953^{*}$ & $1.225027^{*}$ \\
\hline Ket: $^{*}$ lag & optimal
\end{tabular}

Ket: *lag optimal

Berdasarkan tabel 4 dapat dilihat bahwa nilai absolut terendah pada AIC dan SC berada pada lag 3 dengan nilai absolut 0.564953 dan 1.225027. Dengan demikian seluruh indikator merekomendasikan lag 3 sebagai lag optimal.

\section{Uji Panjang Kelambanan (lag) Optimal IKNB Syariah}

Berikut hasil pengujian lag optimal pada IKNB Syariah:

\section{Tabel 5}

Hasil Pengujian Lag Optimal IKNB Syariah

\begin{tabular}{ccccccc}
\hline Lag & LogL & LR & FPE & AIC & SC & HQ \\
\hline o & 2.813 .981 & NA & 0.000703 & -1.584 .231 & -1.493 .533 & -1.553 .714 \\
1 & 8.649 .863 & $106.1070^{*}$ & $2.61 \mathrm{e}-05^{*}$ & $-4.878705^{*}$ & $-4.606613^{*}$ & $-4.787154^{*}$ \\
2 & 8.939 .076 & 4.907 .858 & $2.80 \mathrm{e}-05$ & -4.811 .561 & -4.358 .074 & -4.658 .977 \\
\hline
\end{tabular}

Ket: *lag optimal

Tabel 5 menunjukkan bahwa baik indikator AIC maupun SC merekomendasikan lag 1 sebagai lag optimal. Dengan demikian, maka dapat disimpulkan bahwa lag optimal untuk variabel IKNB Syariah dan IPI adalah lag 1. 
270|Kontribusi Industri Keuangan Non-Bank (IKNB) Konvensional dan Syariah

Terhadap Perekonomian Indonesia

\section{Uji Stabilitas VAR/VECM IKNB Konvensional}

Berikut merupakan hasil uji stationeritas pada variabel IKNB Konvensional dan IPI:

Tabel 6

\begin{tabular}{cc} 
Hasil Uji Stabilitas VAR/VECM IKNB Konvensional \\
\hline \multicolumn{1}{c}{ Root } & Modulus \\
\hline 0.964039 & 0.964039 \\
$0.701206-0.551790 \mathrm{i}$ & 0.892279 \\
$0.701206+0.551790 \mathrm{i}$ & 0.892279 \\
$-0.238546-0.625896 \mathrm{i}$ & 0.669813 \\
$-0.238546+0.625896 \mathrm{i}$ & 0.669813 \\
-0.548499 & 0.548499 \\
No root lies outside the unit circle. & \\
VAR satisfies the stability condition. & \\
\hline
\end{tabular}

Seluruh nilai modulus pada tabel $6<1$, maka dapat disimpulkan bahwa model yang dibangun stabil.

\section{Uji Stabilitas VAR/VECM IKNB Syariah}

Berikut merupakan hasil pengujian stabilitas pada variabel IKNB Syariah dan IPI:

\section{Tabel 7}

Hasil Uji Stabilitas VAR/VECM IKNB Syariah

\begin{tabular}{lc}
\hline \multicolumn{1}{c}{ Root } & Modulus \\
\hline-0.238419 & 0.238419 \\
0.191759 & 0.191759 \\
No root lies outside the unit circle. & \\
VAR satisfies the stability condition. & \\
\hline
\end{tabular}

Hasil di atas diperkuat dengan keterangan "No root lies outside the unit circle. VAR satisfies the stability condition"

\section{Estimasi VAR}

Berikut hasil estimasi VAR pada IKNB Konvensional:

\section{Tabel 8}

Hasil Estimasi VAR IKNB Konvensional

\begin{tabular}{lll}
\hline \multirow{2}{*}{ Variabel Sistem VAR } & \multicolumn{2}{c}{ T-statistik } \\
\cline { 2 - 3 } & IKNB_K & \multicolumn{1}{c}{ IPI } \\
\hline IKNB_K(-1) & $4,25518^{* * * *}$ & 0,58297 \\
IKNB_K(-2) & $-0,27704$ & $-1,25686$ \\
IKNB_K(-3) & $-1,07806$ & $2,49381^{* *}$ \\
LNIPI(-1) & $-1,60161$ & $2,99784^{* * *}$ \\
LNIPI(-2) & 1,17903 & 0,46208 \\
LNIPI(-3) & $2,02964^{*}$ & 0,68985 \\
Nilai kritis t-statistik, n=32, $\boldsymbol{d} \boldsymbol{f}=\mathbf{3 0}$ \\
1\% & $-2,75000$ & 2,75000 \\
5\% & $-2,04227$ & 2,04227 \\
10\% & $-1,69726$ & 1,69726 \\
\hline
\end{tabular}

Ket: ${ }^{* * *},{ }^{* *}, *$ menunjukkan data signifikan pada nilai kritis t-statistik $1 \%, 5 \%, 10 \%$

Hasil estimasi pada tabel 8 menunjukkan bahwa IKNB_K(-1) dan LNIPI(-3) berpengaruh positif dan signifikan sebesar 4,25518 dan 2,02964 terhadap IKNB_K. Adapun IKNB_K(-3) dan LNIPI(-1) juga berpengaruh positif dan signifikan terhadap IPI sebesar 
masing-masing 2,49381 dan 2,99784. Hasil estimasi tersebut dapat disimpulkan bahwa IKNB Konvensional dan IPI memiliki hubungan saling mempengaruhi yang signifikan satu sama lain.

\section{Uji Kointegrasi Johansen}

Hasil uji kointegrasi IKNB Syariah dan IPI dapat dilihat pada tabel 9 di bawah ini:

\section{Tabel 9}

Hasil Uji Kointegrasi Johansen IKNB Syariah

\begin{tabular}{ccccc}
\hline $\begin{array}{c}\text { Hypothesized } \\
\text { No. of CE(s) }\end{array}$ & Eigen value & $\begin{array}{c}\text { Trace } \\
\text { Statistic }\end{array}$ & $\begin{array}{c}\text { o.o5 } \\
\text { Critical Value }\end{array}$ & Prob. $^{* *}$ \\
\hline None * & 0.484410 & 30.74906 & 25.87211 & 0.0114 \\
At most 1 & 0.174442 & 6.901062 & 12.51798 & 0.3549 \\
\hline \multicolumn{4}{r}{ Trace test indicates 1 cointegrating eqn(s) at the 0.05 level } \\
* denotes rejection of the hypothesis at the 0.05 level \\
**MacKinnon-Haug-Michelis (1999) p-values
\end{tabular}

Hasil uji kointegrasi Johansen menunjukkan nilai trace statistic sebesar 30.74906 lebih besar dari nilai kritis pada alpha $5 \%$ yaitu 25.87211 berarti terdapat satu kointegrasi dalam persamaan yang dibangun. Dengan demikian kedua variabel yang diuji (IKNB Syariah dan IPI) terkointegrasi sehingga model VECM dapat dilakukan dalam penelitian ini.

\section{Uji Kausalitas Granger IKNB Konvensional}

Uji kausalitas pada penelitian ini menggunakan VAR Pairwise Granger Causality Test dengan menggunakan tingkat signifikansi 10\%.

Hasil uji kausalitas Granger pada variabel IKNB Konvensional dan IPI adalah sebagai berikut:

\section{Tabel 10}

Hasil Uji Kausalitas Granger IKNB Konvensional

\begin{tabular}{cccc}
\hline Lag & Null Hypothesis & Obs & Prob \\
\hline \multirow{2}{*}{ Lag 3} & LNIPI does not Granger Cause IKNB_K & 29 & $0.0113^{* *}$ \\
& IKNB_K does not Granger Cause LNIPI & $29.0826^{*}$ \\
\hline Ket: ${ }^{* *}$ dan ${ }^{*}$ menunjukkan signifikan pada $\alpha=5 \%, \alpha=10 \%$,
\end{tabular}

Tabel 10 menunjukkan bahwa variabel IPI secara statistik mempengaruhi IKNB Konvensional pada taraf kepercayaan 95\% dengan nilai probabilitas sebesar 0,0113. Hal serupa juga terjadi pada variabel IKNB Konvensional. Variabel IKNB Konvensional mempengaruhi IPI pada taraf kepercayaan 90\% dengan nilai probabilitas sebesar 0,0826.

\section{Uji Kausalitas Granger IKNB Syariah}

Tabel 11 berikut menunjukkan hasil uji kausalitas Granger pada variabel IKNB Syariah dan IPI:

\section{Tabel 11}

Hasil Uji Kausalitas Granger IKNB Syariah

\begin{tabular}{clcc}
\hline Lag & \multicolumn{1}{c}{ Null Hypothesis } & Obs & Prob \\
\hline \multirow{2}{*}{ Lag 1} & $\begin{array}{l}\text { LNIPI does not Granger Cause IKNB_S } \\
\text { IKNB_S does not Granger Cause LNIPI }\end{array}$ & 37 & $\begin{array}{c}0.0075^{* * *} \\
0.0992^{*}\end{array}$ \\
\hline Ket: $^{* * *}$ dan & $*$ menunjukkan signifikan pada $\alpha=1 \%, \alpha=10 \%$,
\end{tabular}


Tabel 11 juga menjelaskan bahwa variable IPI secara statistik mempengaruhi IKNB Syariah dengan nilai probabilitas o,o075, sedangkan IKNB Syariah mempengaruhi IPI dengan nilai probabilitas 0,0992.

\section{Impulse Response Function (IRF) IKNB Konvensional}

Berikut hasil dari analisis IRF pada variabel IKNB Konvensional dan IPI:

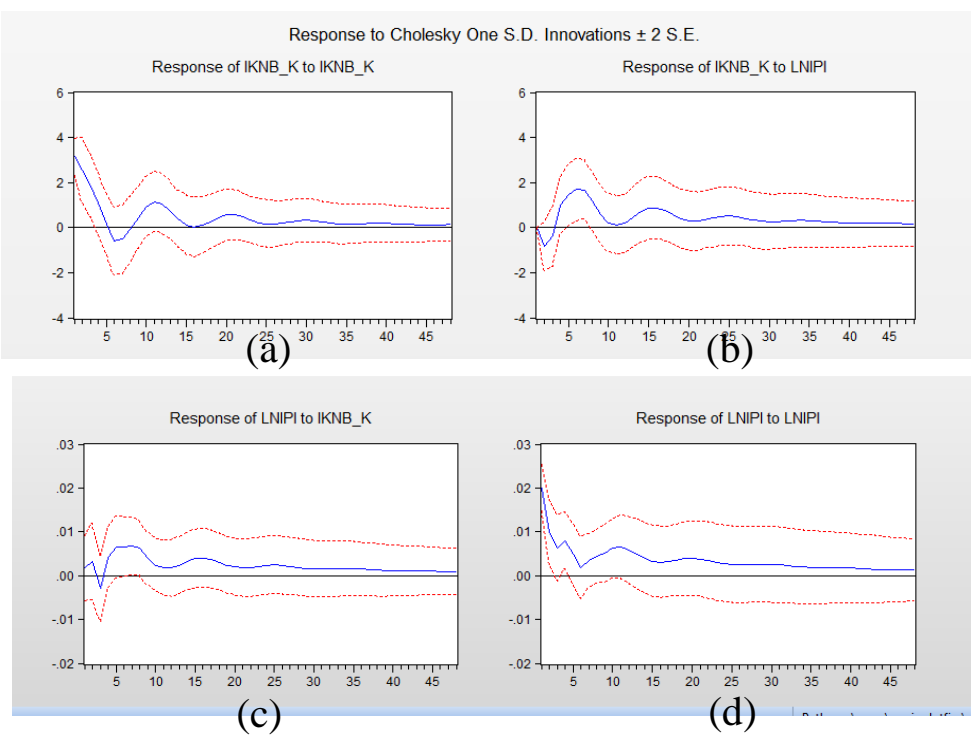

Gambar 3 Hasil Uji IRF IKNB Konvensional

Gambar 3(a) menunjukkan bahwa respon yang diberikan IKNB Konvensional terhadap shock yang ditimbulkan oleh variabel itu sendiri positif pada awal periode, namun terus berfluktuatif hingga stabil pada periode ke-44 dengan standar deviasi sebesar 0,1. Disisi lain, gambar 3(b) menunjukkan bahwa respon IKNB Konvensional terhadap shock yang ditimbulkan variabel IPI secara umum adalah respon positif dan terus berfluktuasi dengan trend menurun hingga stabil pada periode ke-46 dengan standar deviasi sebesar 0,2.

Adapun gambar 3(c) menunjukkan bahwa respon IPI terhadap shock yang ditimbulkan oleh variabel IKNB Konvensional secara keseluruhan adalah positif. Respon negatif hanya terjadi pada periode ke-3 hingga periode ke-4. Pada periode ke- 5 respon mulai positif dan terus berfluktuasi hingga stabil pada peiode ke-47 dengan standar deviasi sebesar 0,001. Gambar 3(d) menggambarkan respon positif yang diberikan oleh IPI terhadap shock yang terjadi pada dirinya sendiri. Respon tersebut terus berfluktuktuasi hingga stabil pada periode 43 dengan standar deviasi 0,001.

\section{Impulse Response Function (IRF) IKNB Syariah}

Berikut hasil Uji Impulse Response Function pada IKNB Syariah selama 48 periode kedepan: 


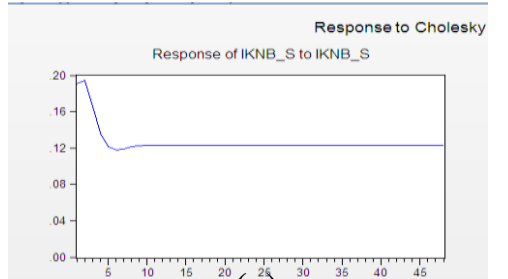

(a)

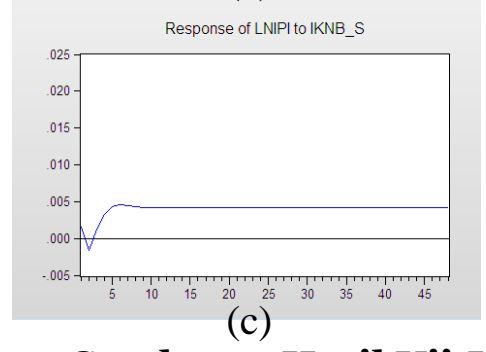

Gambar 4 Hasil Uji Impuls Response Function (IRF) IKNB Syariah

Gambar 4(a) menujukkan bahwa respon IKNB Syariah terhadap shock dari dirinya sendiri dalam 48 periode mendatang secara keseluruhan adalah positif. Respon mulai stabil pada period ke-9 hingga akhir periode pengamatan dengan standar deviasi sebesar 0,123. Dari gambar 4(b) dapat dilihat bahwa shock yang ditimbulkan oleh IPI direspon positif oleh IKNB Syariah pada seluruh periode pengamatan. Respon terus berfluktuasi dari awal periode hingga akhirnya stabil pada periode ke-9 dengan standar deviasi sebesar 0,170.

Adapun gambar 4(c) menunjukkan bahwa shock yang ditimbulkan oleh IKNB Syariah direspon positif oleh IPI pada periode pertama dengan standar deviasi sebesar 0,0016. Namun pada periode ke-2 hingga periode ke-3, shock tersebut direspon negatif oleh IPI dengan standar deviasi sebesar -0,0016. Kemudian pada periode selanjutnya IPI mulai merespon positif shock tersebut hingga stabil pada periode ke-9 dengan standar deviasi sebesar 0.0042. Sedangkan gambar 4(d) menggambarkan respon positif IPI terhadap shock dari variabel itu sendiri pada seluruh periode penelitian. Respon yang diberikan sangat bagus pada awal periode, namun terus berfluktuasi dengan trend menurun. Fluktusi tersebut berakhir pada periode ke-9 dengan standar deviasi 0,0058.

\section{Forecast Error Decomposition Variance IKNB Konvensional}

Berikut hasil pengujian FEDV pada variabel IKNB Konvensional dan IPI:

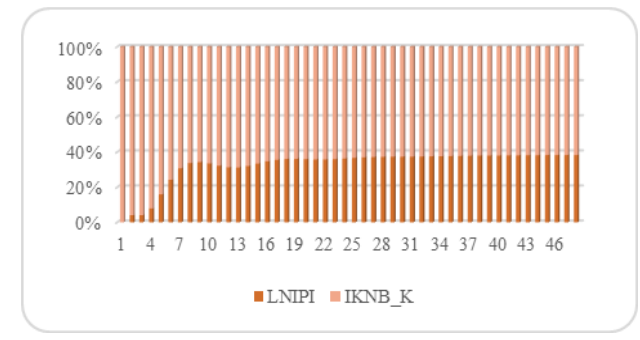

Gambar 5

Hasil Uji FEDV Variabel IKNB Konvensional

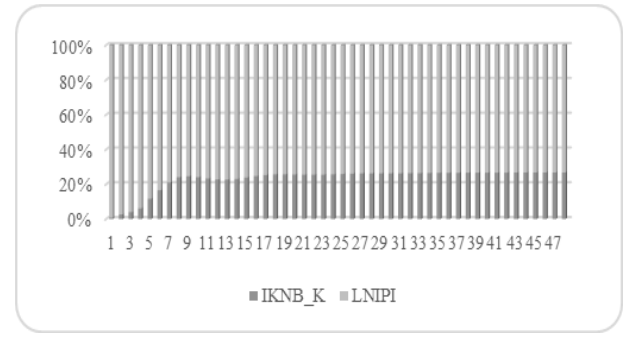

Gambar 6

Hasil Uji FEDV Variabel IPI

At-Tijaroh : Jurnal Ilmu Manajemen dan Bisnis Islam, Volume 5, Nomor 2 Tahun 2019 http://jurnal.iain-padangsidimpuan.ac.id/index.php/attijaroh 
Dari gambar 5 dapat dilihat bahwa kontribusi terbesar pada varian variabel IKNB Konvensional adalah varian atau shock dari variabel itu sendiri. Kontribusi variabel IKNB Konvensional pada awal periode sebesar 100\% namun terus menurun hingga akhir periode pengamatan sebesar $61,64 \%$. Walaupun demikian variabel ini tetap mendominasi karena shock pada variabel IPI hanya berkontribusi sebesar 4,09\% pada periode ke-2 dan 38,35\% pada akhir periode penelitian.

Disisi lain, gambar 6 menunjukkan bahwa kontribusi terbesar pada varian variabel IPI adalah shock dari variabel itu sendiri. Kontribusi variabel IPI pada awal periode sebesar 99,23\% namun terus menurun hingga akhir periode pengamatan sebesar 73,22\%. Walaupun demikian variabel ini tetap mendominasi karena shock pada variabel IKNB Konvensional hanya berkontribusi sebesar 0,76\% pada periode pertama dan terus bertambah hingga $26,77 \%$ pada akhir periode penelitian.

\section{Forecast Error Decomposition Variance IKNB Syariah}

Berikut hasil pengujian FEDV IKNB Syariah:

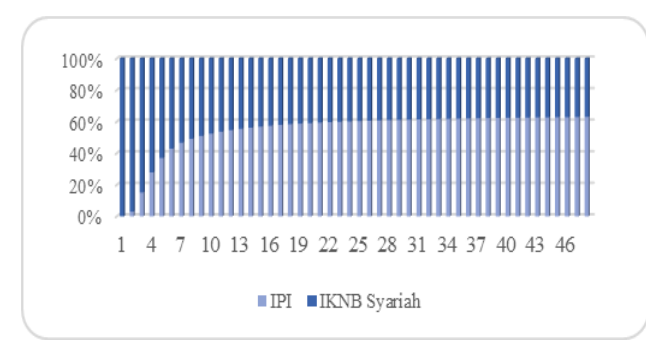

Gambar 7

Hasil Uji FEDV Variabel IKNB Syariah

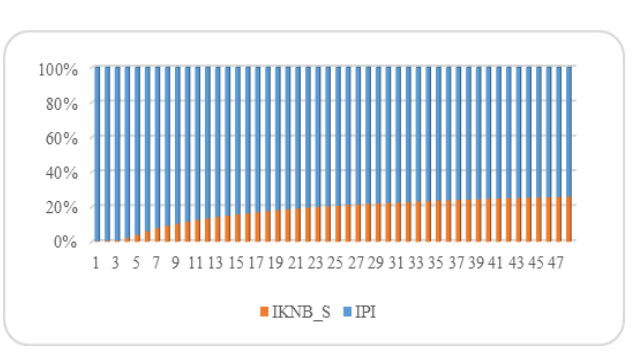

Gambar 8

Hasil Uji FEDV Variabel IPI

Berdasarkan Gambar 7 di atas terlihat bahwa variabel IPI dan IKNB Syariah itu sendiri memiliki pengaruh yang hampir sama kuat pada pergerakan variabel IKNB Syariah. Namun shock dari variabel IPI lebih dominan mempengaruhi pergerakan pada variabel IKNB Syariah sebesar 62,99\% pada periode ke-48. Sedangkan shock dari variabel IKNB Syariah itu sendiri berpengaruh sebesar 100\% pada periode pertama, akan tetapi pengaruh tersebut terus menurun hingga 37,007 pada periode ke-48.

Pada analisis berikutya, pergerakan pada variabel IPI dominan dipengaruhi oleh variabel itu sendiri sebesar 99,52\% pada periode pertama dan terus menurun hingga 74,05\% pada periode ke-48 dengan nilai rata-rata sebesar 82,04\%. Sedangkan variabel IKNB Syariah hanya mampu menjelaskan variabel IPI sebesar 0,48\% pada periode pertama dan kontribusi variasinya terus mengalami peningkat hingga periode ke-48 dengan prosentase kontribusi sebesar 25,95\%. Hal ini membuktikan bahwa IKNB Syariah memiliki pengaruh positif yang relatif kecil terhadap pergerakan pertumbuhan ekonomi. 


\section{Analisis Hubungan Kausalitas antara Perkembangan IKNB Konvensional dan IKNB Syariah terhadap Pertumbuhan Ekonomi}

Hasil uji kausalitas Granger pada kedua model yang dibangun, menunjukkan bahwa hubungan yang terjadi antara perkembangan sektor keuangan (IKNB Konvensional dan IKNB Syariah) dan pertumbuhan ekonomi merupakan hubungan timbal balik sesuai dengan hipotesis "the bidirectional causality view", dimana perkembangan IKNB Konvensional dan IKNB Syariah akan mempengaruhi pertumbuhan ekonomi dan begitu pula sebaliknya, perekonomian yang tumbuh tersebut akan menanbah permintaan terhadap produk IKNB Konvensional dan Syariah, yang pada akhirnya akan mendorong perkembangan IKNB Konvensional maupun Syariah.

Hasil pengujian kausalitas Granger tersebut diperkuat dengan hasil dari pengujian IRF dan FEDV. Uji IRF pada IKNB Konvensional menunjukkan bahwa variabel tersebut memberikan respon yang positif pada shock yang ditimbulkan oleh IPI, begitu pula sebaliknya. Hal ini berarti bahwa ketika IKNB Konvensional berkembang, maka akan mendorong pertumbuhan ekonomi dan ketika ekonomi tumbuh, maka akan meningkatkan perkembangan IKNB Konvensional.

Meskipun demikian, respon yang diberikan pada kedua pengujian relatif kecil. Hal ini dibuktikan dengan nilai standar deviasi kedua pengujian tersebut yang mendekati garis amatan yaitu sebesar 0,2 pada respon IKNB Konvensional terhadap shock IPI dan 0.001 pada respon IPI terhadap shock IKNB Konvensional. Selain itu, dibutuhkan waktu yang lama bagi kedua pengujian untuk mencapai titik kestabilan. Respon IKNB Konvensional terhadap shock IPI stabil pada periode 46, sedangkan respon IPI terhadap shock IKNB Konvensional stabil pada periode 47 .

Kemudian uji FEDV menujukkan bahwa kontribusi IKNB Konvensional terhadap varian pergerakan IPI relatif kecil, IKNB Konvensional hanya menyumbang variasi pergerakan sebesar 32,87\%. Pergerakan IPI masih didominasi oleh variabel itu sendiri sebesar $67,12 \%$. Hal ini juga terjadi pada pergerakan IKNB Konvensional, pergerakannya didominasi oleh kontribusi variabel itu sendiri sebesar 76,76\%, sedangkan variabel IPI hanya berkontribusi sebesar $23,23 \%$.

Uji IRF pada hubungan sektor keuangan yang diproksikan oleh IKNB Syariah terhadap pertumbuhan ekonomi merupakan hubungan yang positif, dengan nilai standar deviasi pada periode stabil yang cukup besar yaitu sebesar 0,042. Hal ini juga didukung dengan hasil uji FEDV yang menyatakan bahwa varian kontribusi yang diberikan perkembangan IKNB Syariah terhadap pertumbuhan ekonomi sebesar 17,96\%. Kontribusi tersebut sudah cukup besar jika dibandingkan dengan kontribusi IKNB Konvensional. Meskipun rasio IKNB Syariah terhadap PDB hanya bernilai rata-rata $6,4 \%$ 
IKNB Syariah dapat lebih berkontribusi terhadap pertumbuhan sektor riil dan ekonomi karena lembaga keuangan syariah adalah lembaga yang lebih menekankan konsep asset and production base system (sistem berbasis aset dan produksi) sehingga melalui pola demikian maka sektor riil dan sektor keuangan akan bergerak secara seimbang. Akibatnya semakin pesat perkembangan IKNB Syariah maka akan semakin besar kontribusinya terhadap kinerja dan pertumbuhan ekonomi (Rama, 2011: 19).

Adapun uji IRF dan FEDV pertumbuhan ekonomi terhadap IKNB Syariah menunjukkan bahwa pertumbuhan ekonomi berkontribusi positif dengan standar deviasi sebesar 0,71 dan kontribusi varian sebesar 17,65\%. Hal ini mengindikasikan bahwa pertumbuhan ekonomi merupakan salah satu faktor pendorong perkembangan IKNB Syariah. Pertumbuhan ekonomi yang stabil akan terus meningkatkan perkembangan IKNB Syariah baik dari sisi aset maupun investasi.

Berdasarkan hasil uji IRF dan FEDV pada IKNB Konvensional dan IKNB Syariah terhadap IPI dapat ditarik kesimpulan bahwa sektor keuangan (IKNB Konvensional dan Syariah) berpengaruh positif terhadap pertumbuhan ekonomi Indonesia, begitu pula sebaliknya. Hasil ini sesuai dengan penelitian yang pernah dilakukan oleh Odedokun (1992); Luintel dan Khan (1999); Demetriades dan Husaen (1996); Habibullah (1999); Unalmis (2002); Islam (2007).

Hasil uji IRF dan FEDV juga membuktikan bahwa kontribusi yang diberikan oleh IKNB Konvensional dan Syariah terhadap pertumbuhan ekonomi relatif kecil. Artinya IKNB Konvensional dan Syariah belum mampu memaksimalkan potensinya sebagai lembaga intermediasi keuangan yang berkontribusi terhadap pertumbuhan ekonomi. Oleh karena itu, diperlukan peran pemerintah yang besar guna mengembangkan sektor IKNB khususnya IKNB Syariah. Hal ini disebabkan karena IKNB Syariah terbukti lebih tahan terhadap shock dibanding IKNB Konvensional. Hal tersebut dapat dilihat dari standar deviasi periode yang dibutuhkan IKNB Syariah untuk mencapai kestabilan setelah terkena shock adalah sebanyak 9 periode, sedangkan IKNB Konvensional membutuhkan waktu yang lebih lama untuk mencapai kestabilan yaitu 47 periode.

\section{Analisis Hubungan Jangka Panjang antara Perkembangan IKNB Konvensional dan IKNB Syariah terhadap Pertumbuhan Ekonomi}

IKNB Konvensional stationer pada tingkat level. Oleh karena itu analisis hubungan jangka panjang dilakukan melalui estimasi VAR. Hasil estimasi VAR yang telah dilakukan menunjukkan bahwa perkembangan IKNB Konvensional memiliki hubungan jangka panjang dengan pertumbuhan ekonomi. Hasil ini sesuai dengan penelitian Islam dan Shah (2012); Rateiwa dan Aziakpono (2015). Berbeda dengan IKNB Konvensional, model IKNB Syariah dan IPI tidak stationer pada tingkat level maka model diduga memiliki kointegrasi. Berdasarkan 
hasil uji Kointegrasi Johansen, model IKNB Syariah memiliki 1 persamaan kointegrasi dengan nilai trace statistic sebesar 29.93971 lebih besar dari nilai kritis pada alpha 5\% yaitu 25.87211 . Persamaan kointegrasi yang ada dalam model tersebut menunjukkan bahwa perkembangan IKNB Syariah juga memiliki hubungan jangka panjang dengan pertumbuhan ekonomi di Indonesia.

Implikasi dari hasil tersebut adalah perkembangan sektor keuangan (IKNB Konvensional dan IKNB Syariah) dan pertumbuhan ekonomi akan saling mempengaruhi di masa yang akan datang dengan menganggap variabel lain tidak ada (disturbance term). Sehingga dapat diartikan bahwa baik IKNB Konvensional maupun Syariah mampu menjalankan fungsinya sebagai sektor jasa keuangan jangka panjang, yang berkontribusi terhadap bertumbuhan ekonomi yang berkelanjutan (Al-Arif, 2012: 81).

Hubungan positif jangka panjang yang terjadi pada IKNB khususnya IKNB Syariah mencerminkan bahwa lembaga keuangan dapat menciptakan pertumbuhan ekonomi yang berkelanjutan. Pada akhirnya akan mendorong tercapainya distribusi pendapatan yang adil sesuai dengan makna pertumbuhan ekonomi dalam Islam yaitu tidak hanya mementingkan besarnya pendapatan akan tetapi, bagaimana pendapatan tersebut dapat didistribusikan kepada seluruh masyarakat (Huda, dkk, 2015: 124-125).

\section{KESIMPULAN}

Penelitian ini menunjukkan bahwa hubungan yang terjadi antara sektor keuangan (IKNB Konvensional dan IKNB Syariah) terhadap pertumbuhan ekonomi merupakan hubungan kausalitas dua arah (bidirectional causality view) positif yang berarti bahwa perkembangan IKNB Konvensional dan Syariah akan mendorong laju pertumbuhan ekonomi, begitu pula sebaliknya petumbuhan ekonomi akan meningkatkan permintaan terhadap sektor keuangan (IKNB Konvensional dan IKNB Syariah). Di samping itu, sektor keuangan berbasis Syariah dinilai lebih tahan terhadap shock yang terjadi pada pertumbuhan ekonomi maupun variable itu sendiri dibandingkan dengan sektor keuangan konvensional. Mengingat semakin besarnya kontribusi sektor IKNB, khususnya IKNB syariah terhadap perkonomian, maka kiranya perlu diperkuat lagi peranan pemerintah terhadap sektor ini. Berbagai regulasi yang dibutuhkan bagi pengembangan sektor IKNB perlu diorientasikan bagi kemudahan pengembangannya, tanpa mengurangi prinsip kehati-hatian sebagai lembaga intermediasi keuangan. Selain itu edukasi dan sosialisasi kepada berbagai komunitas dan ormas keislaman juga perlu semakin ditingkatkan, seperti NU dan Muhammadiyah, karena merekalah yang secara sosial dan kultural mampu menggerakkan potensi ekonomi ummat.

\section{DAFTAR PUSTAKA}


Al-Arif, Muhammad Nur Rianto. 2012. Lembaga Keuangan Syariah Suatu Kajian Teoritis dan Praktis.Bandung: Pustaka Setia.

Alderman, H., Yemtsov, R.. 2013. How can safety nets contribute to economic growth? Working Paper 6437, World Bank, Washington, DC

Al-Zubi, K., et. al. 2006. Financial Development and Economic Growth: A New Empirical Evidance from the Mena Countries 1989-2001. Journal of Applied Econometrics and International Development, Vol, 6, No.1, hlm. 3-11.

Arestis, P. dan P. Demetriades. 1996. Finance and Growth: Institutional Consideration and Causality. UEL Depertement of Economics Working Paper.

Baroroh, Utami. 2012. Analisis Sektor Keuangan Terhadap Pertumbuhan Ekonomi Regional di Wilayah Jawa: Pendekatan Model Levine. Jurnal Etikonomi Vol. 11. No. 2.

Black burn, K. dan Hung, V.T.Y. 1998. A Theory of Growth, Financial Development and Trade. Economica. Vol.3, No. 65, hlm. 107-124.

Chapra, Umar. 2008. The Global Financial Crisis: Can Islamic Finance Help Minimize The Severity Ana Frequency of Such A Crisis in The Future?. A Paper presented at The Forum on The Global Financial Crisis, Islamic Development Bank

Habibullah, M.Z., and Eng, Y.K. 2006. Does financial development cause economic growth? a panel data dynamic analysis for Asian developing countries. Journal of the Asian Pacific Economy. Vol. 11, No. 4, hlm. 377-393.

Haiss, P. dan Sumegi, K. 2008. The Relationship between Insurance and Economic Growth in Europe: A Theoritical and Empiris Analysis. Empirica Vol 35. Helm. 405-431

Harrison, P., et. al. 1999. Finance and Growth: Theory and New Evidance. Federal Reserve Board Finance and Economics Discussion Paper. 1999-35.

Hossain, M., \& Shahiduzzaman, M. 2002. Development of Non Bank Financial Institutions to Strengthen the Financial System of Bangladesh. Journal of Bangladesh Institute of Bank Management (BANK PARIKRAMA), 28(1).

Huda, Nurul, dkk. 2015. Ekonomi Pembangunan Islam. Jakarta: Kencana Predana Media Group.

Islam, Mohd Aminul Islam, Jalan Sultan Ahmad Shah. 2012. An Empirical Analysis of Causality between Development of Non-Bank Financal Intermediaries and the Economic Growth in Malaysia. European Journal of Social Science, Vol. 30, No. 4.

King, R.G. and Levine, R. 1993. Finance, Entrepreneurship, and Growth. Journal of Monetary Economics. 32, hlm. 513-542.

Levine, R. 1997. Financial development and economic growth: views and agenda. Journal of Economic Literature. 35(2), hlm. 688-726.

Lucas, R.E. 1988. On the mechanics of economic development. Journal of Monetary Economics. 22(1), hlm. 3-42.

Luintel, K. B., and M. Khan. 1999. A Quantitative Reassessment of the Finance-Growth Nexus: Evidance from A Multivariate VAR. Journal of Development Economics. 6o, hlm. 381405.

Meng, C. dan Pfau, W. 2010. Role of Pension Funds in Capital Market Development. GRIPS Discussion Paper.

Mishkin, Frederic S. 2010. The Economics of Money, Banking, and Financial

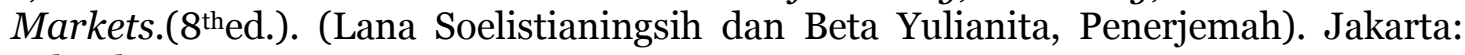
Salemba Empat.

Nath, Bidduth Kanti., dkk. 2012. Prospek of Non Bank Financial Institutions \& Money Market: Indication krom Bangladesh.

Odedokun, M. O. 1992. Supply-Leading and Demand-Following Relationship between Activity and Development Banking in Developing Countries: An Empirical Analysis. Singapore Economic Review. 37, hlm. 46-58.

Otoritas Jasa Keuangan. 2015. Roadmap IKNB Syariah. Otoritas Jasa Keuangan http://www.ojk.go.id/id/kanal/syariah/berita-dan- 
kegiatan/publikasi/Documents/Pages/Roadmap-Pasar-IKNB-2015-2019/roadmapnbs_2015-2019.pdf

Otoritas Jasa Keuangan. 2016. Master Plan Sektor Jasa Keuangan Indonesia 2015-2019. Jakarta: Penulis

Otoritas Jasa Keuangan. 2017. Ikhtisar Data Keuangan IKNB dan IKNB Konvensional. Jakarta: Penulis.

Rama, Ali. 2013. Perbankan Syariah dan Pertumbuhan Ekonomi Indonesia. Jurnal

Signifikan Vol. 2, No. 1.

Rateiwa, Ronald dan Aziakpono, Meschah Jesse. 2015. Non-Bank Financial Institution and Economic Growth: Evidence from Selected African Countries.

Schumpeter, J.A. 1912. A Theory of Economic Development. Cambridge, MA: Harvard University Press. 